\title{
Analisis Peningkatan Kualitas Pelayanan dengan Quality Function Deployment (QFD) pada Laboratorium Matematika Pusat Laboratorium Terpadu
}

\author{
Yanne Irene, Bambang Ruswandi \\ Matematika FST UIN Syarif Hidayatullah Jakarta \\ Email : yanne.irene@uinjkt.ac.id
}

\begin{abstract}
ABSTRAK
Penelitian ini dilakukan untuk mengeksplorasi faktor-faktor yang berpengaruh terhadap kualitas pelayanan Laboratorium Matematika Pusat laboratorium Terpadu serta merencanakan strategi peningkatan kualitas pelayanan dengan menggunakan Metode Quality Function Deployment (QFD). Dari hasil eksplorasi terhimpun sebanyak 30 mahasiswa, kemudian 30 atribut tersebut di ekstrasi dengan menggunakan metode Eksplorasi Faktor Analisis (EFA) dan diperoleh 9 komponen utama. Untuk memenuhi harapan dan keinginan mahasiswa tersebut, maka pihak prodi memberikan lima tanggapan teknis responsivenss dan tingkat tangibles. Dari lima respon tersebut, yang menjadi prioritas utama adalah tingkat tangibles yang mampu memenuhi 44,83\% kebutuhan mahasiswa terhadap pelayanan Laboratorium Tugas Matematika dan yang menjadi prioritas terakhir adalah tingkat Emphaty dengan nilai prioritas $11,19 \%$
\end{abstract}

Kata Kunci: Pelayanan, Kualitas, EFA, QFD, Prioritas

\section{ABSTRACT}

This research was conducted to explore the factors that influence the quality of Mathematics Integrrated Laboratory services and to make strategies to improve quality of services by using Quality Function Deployment (QFD) Method. From the results of exploration mustered as many as 30 voice of customer, earn nine main components. To be able to meet the expectation and desires of the student, then study program providing five technical feedback. Of the five responses, which became the top priority is tangibles rate with rate priority is 44,83\% that can meet the need of students towards Mathematics task Performances Laboratory and the last priority is the emphaty with rate of priority is $11,19 \%$.

Keywords:Services, Quality, EFA, QFD, Priority

\section{Pendahuluan}

Sejalan dengan telah terealisasinya Laboratorium Komputer Matematika pada bulan November 2009, maka segenap civitas akademika Program Studi Matematika berupaya untuk senantiasa mengoptimalkan fasilitas yang ada. Setelah hampir 3 tahun berjalan, laboratorium matematika hanya digunakan oleh mahasiswa pada saat jadwal praktikum saja. Sedangkan di luar jadwal tersebut, mahasiswa sangat jarang menggunakan fasilitas laboratorium 
matematika. Dari hasil pengamatan, dapat diidentifikasi bahwa kurangnya minat mahasiswa menggunakan fasilitas Laboratorium Matematika berkaitan dengan kualitas pelayanan yang diberikan manajemen terutama dalam hal aturan penggunaan yang tidak jelas serta fasilitas fisik yang terkait dengan kenyamanan ruangan, fasilitas komputer dan juga internet.

Berdasarkan kualitas pelayanan yang dinilai masih rendah oleh mahasiswa maka penggunaan Lab Matematika oleh mahasiswa menjadi kurang optimal. Oleh sebab itu akan peneliti kelompokkan dengan menggunakan analisis faktor sehingga dapat diketahui faktor-faktor yang berpengaruh terhadap kualitas pelayanan Laboratorium Matematika PLT. Hasil pengelompokkan ini akan ditindaklanjuti dengan menerapkan metode terbaru dalam peningkatan kualitas pelayanan.

Day [1] berpendapat bahwa kegagalan suatu perusahaan dalam memenuhi keinginan konsumen menimbulkan ide yang menjadi salah satu prinsip dalam proses QFD, yaitu mendorong produsen untuk berkomunikasi dengan konsumennya. Dalam proses ini, produsen mempelajari apa yang menjadi keinginan dan kebutuhan konsumen sehingga perusahaan dapat merencanakan strategi untuk meningkatkan kepuasan konsumen. Menurut Jack [3] penerapan metode ini dalam pengembangan kualitas diawali dengan pembentukan matriks atau sering disebut sebagai House Of Quality $(H O Q)$.Matriks ini menerjemahkan apa yang diinginkan konsumen menjadi apa yang dihasilkan organisasi sehingga pelayanan yang dihasilkan akan dapat memenuhi keinginan konsumen. Oleh karena itu, penerapan metode QFD diperlukan dalam peningkatan kualitas pelayanan laboratorium matematika kepada mahasiswa.Kualitas merupakan suatu kondisi dinamis yang berhubungan dengan produk, manusia, proses, dan lingkungan yang memenuhi atau melebihi harapan seperti yang disebut oleh Yamit dalam [5]. Kualitas kecocokan menurut Montgomery [4] adalah seberapa baik produk itu sesuai dengan spesifikasi dan kelonggaran yang disyaratkan oleh rancangan itu.

\subsection{Analisa Komponen Utama}

\section{Tinjauan Pustaka}

Analisis komponen utama mengubah kumpulan variabel awal ke dalam kumpulan variabel (komponen) yang lebih kecil yang merupakan kombinasi linier variabel awal.PC $C_{1}$ (Principal Componen 1) menjelaskan variansi data terbanyak, disusul dengan $\mathrm{PC}_{2}$ dan seterusnya sampai $P C_{n}$ sehingga jumlah variansi yang dijelaskan oleh semua $P C=100 \%\left(\sum P C=100 \%\right)$ dan $n=$ jumlah variabel.

Bentuk umum analisis komponen utama

$$
P C_{m}=w_{(m) 1} X_{1}+w_{(m) 2} X_{2}+\cdots+w_{(m) p}
$$




\subsection{Faktor-Faktor dalam Analisis Komponen Utama}

Dalam analisis komponen utama akan dicari sekumpulan variabel baru, yaitu $F_{1}, F_{2}, \ldots, F_{p}$ yang tidak saling berkorelasi. Variabel-variabel ini disebut sebagai komponen utama yang digunakan untuk mempresentasikan variansi dari variabel awal/observasi. Maka secara umum dapat dinyatakan bahwa komponen utama ke-j dari sampel pengamatan $p$ variabel adalah kombinasi linier dari :

$$
\begin{gathered}
F_{1}=a_{11} x_{1}+a_{12} x_{2}+\cdots+a_{1 p} x_{p} \\
F_{2}=a_{21} x_{1}+a_{22} x_{2}+\cdots+a_{2 p} x_{p} \\
\vdots \\
F_{p}=a_{p 1} x_{1}+a_{p 2} x_{2}+\cdots+a_{p p} x_{p}
\end{gathered}
$$

Nilai-nilai komunalitas dalam tiap baris menunjukkan besarnya variansi yang dapat dijelaskan oleh semua faktor.Nilai komunalitas suatu variabel yang besar menyatakan bahwa sebagian besar varians dalam variabel tersebut telah diekstrak oleh solusi faktor.Sedangkan nilai kecil meperlihatkan bahwa variabel tersebut agak berbeda dengan variabel lainnya dalam analisis.

\subsection{Quality Function Deployment}

Quality Function Deployment (QFD) adalah suatu metode untuk melakukan strukturisasi dalam perencanaan dan perancangan produk atau jasa yang memudahkan organisasi untuk mendefinisikan kebutuhan dan keinginan pelanggan serta kemudian menerjemahkan setiap kebutuhan dan keinginan tersebut ke dalam karakteristik teknis yang relevan Jack[3]. Dari sini dapat dilakukan evaluasi untuk setiap rancangan produk atau jasa secara sistematis sehingga organisasi dapat menghasilkan produk atau jasa yang dapat memenuhi keinginan dan kebutuhan pelanggan.

\subsection{House Of Quality ( HOQ )}

Secara lengkap HOQ dapat dilihat pada Gambar 1.

\section{Metode Penelitian}

Metode penelitian yang digunakan dalam penelitian ini adalah desain deskriptif eksplanatory. Metode deskriptif eksploratif digunakan untuk mengungkapkan variabel-variabel penelitian dan menggambaran secara sistematis dan fakta yang akurat tentang permasalahan yang diteliti. Sedangkan metode yang digunakan untuk mengumpulkan data adalah metode survei dengan alat bantu kuesioner. Dengan metode survei, data dikumpulkan berdasarkan jawaban responden atas daftar pertanyaan yang peneliti ajukan. 


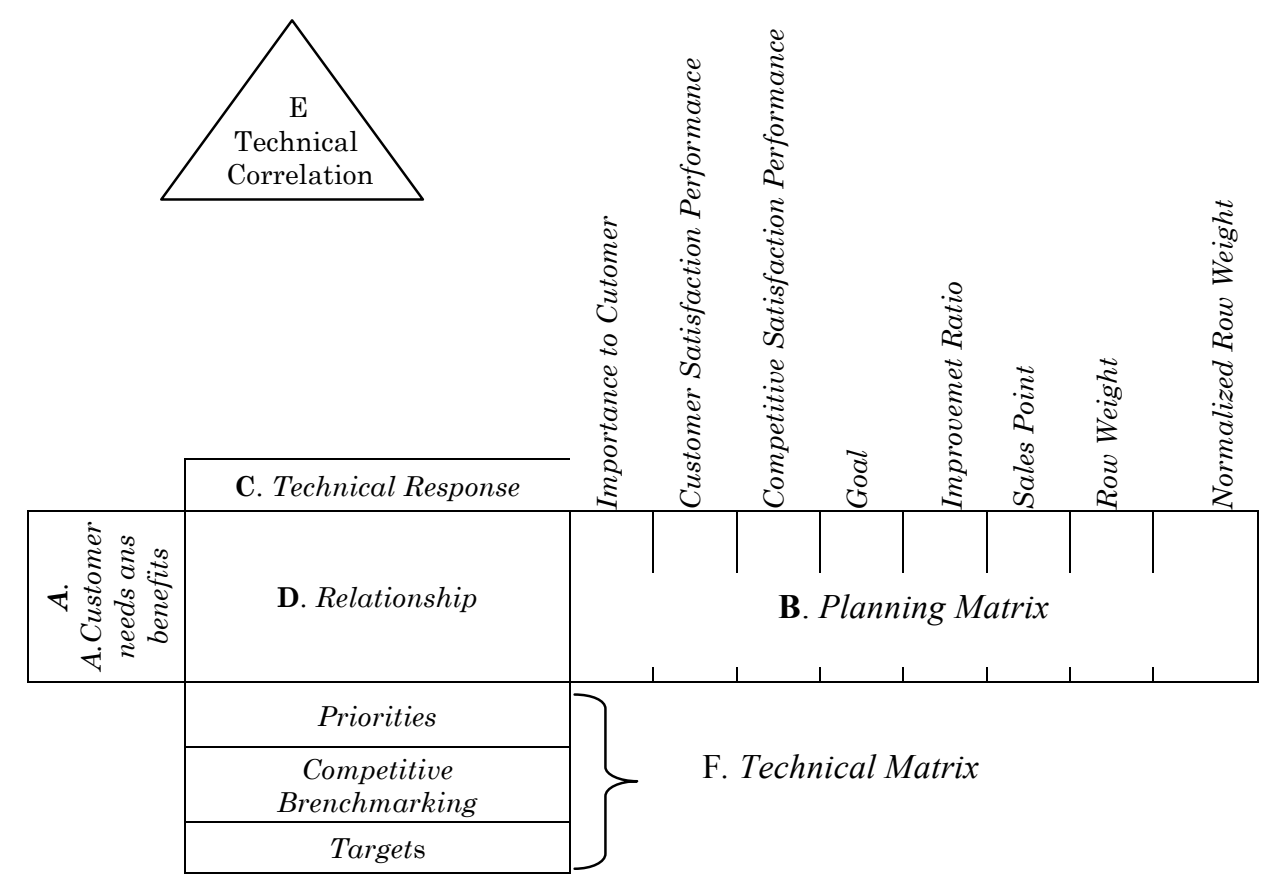

Gambar 1. The house of quality

\section{Hasil dan Pembahasan}

\section{Kuesioner Penelitian Utama}

Untuk dapat melakukan pengukuran harapan dan persfektif mahasiwa terhadap kualitas kinerja layanan laboratorium matematika, dari hasil voice of customer di atas diformulasikan ke dalam bentuk kuesioner penelitian utama. Pada Tabel 1 dapat dilihat hasil formulasi dari hasil penelitian pendahuluan, Dari hasil formulasi kuesioner di atas dengan 30 item pernyataan, maka akan diminta pandangannya kepada mahasiswa mengenai harapan dan realita yang ada untuk analisis selanjutnya yaitu Eksplotari Faktor Analisis dan Quality Function Deployment.

\section{Eksplotari Faktor Analisis}

Eksplotari Faktor Analisis atau disebut juga dengan Analisis faktor pada prinsipnya digunakan untuk mereduksi data yaitu proses untuk meringkas sejumlah faktor menjadi lebih sedikit dan menamakannya sebagai faktor Fandy dan Tjiptono[2]. Perhitungan analisis faktor pada penelitian ini dilakukan dengan program IBM StatisticsSPSS 20versi Trial. 
Tabel 1 Formulasi Kuesioner Penelitian Utama

\begin{tabular}{|c|l|}
\hline \hline No. & \multicolumn{1}{|c|}{ PERNYATAAN } \\
\hline \hline 1 & Respon Laboran terhadap kebutuhan mahasiswa \\
\hline 2 & Keramahan Laboran dalam melayani mahasiswa \\
\hline 3 & Frekuensi Kehadiran Laboran \\
\hline 4 & Kesigapan Laboran dalam memperbaiki komputer yang rusak \\
\hline 5 & Ketepatan Jadwal Penggunaan (Praktikum) \\
\hline 6 & Kesopanan Laboran pada mahasiswa \\
\hline 7 & Kemampuan Laboran dalam mengelola laboratorium \\
\hline 8 & Lama waktu pelayanan laboratorium \\
\hline 9 & Kejelasan pemberian materi oleh dosen praktikum \\
\hline 10 & Ketepatan waktu dosen praktikum mengajar di lab \\
\hline 11 & $\begin{array}{l}\text { Tanggapan dosen praktikum dalam menjawab pertanyaan } \\
\text { mahasiswa }\end{array}$ \\
\hline 12 & Kelengkapan Hardware (Perangkat komputer) \\
\hline 13 & Kelengkapan Software \\
\hline 14 & Kualitas hardware komputer \\
\hline 15 & Jumlah komputer yang tersedia \\
\hline 16 & Ketersediaan Koleksi Buku di ELC \\
\hline 17 & Kerapihan Ruangan Laboratorium \\
\hline 18 & Kenyamanan Ruang Laboratorium \\
\hline 19 & Pengaturan Suhu Laboratorium \\
\hline 20 & Kebersihan ruangan laboratorium \\
\hline 21 & Penerangan Ruangan Laboratorium \\
\hline 22 & Vantilasi Udara \\
\hline 23 & Design Interior \\
\hline 24 & Kondisi Meja komputer dan Kursi mahasiswa \\
\hline 25 & Kapasitas Ruangan Laboratorium \\
\hline 26 & Kelengkapan Saran Pendukung, LCD, webcam, speaker \\
\hline 27 & $\begin{array}{l}\text { Ketersediaan fasilitas intenet, printing, backup data, scanning, } \\
\text { dll }\end{array}$ \\
\hline 28 & Ketepatan penggunaan Lab \\
\hline 29 & Himbauan penggunaan Lab dari Prodi dan Kabid \\
\hline \hline
\end{tabular}


Data yang digunakan dalan perhitungan analisis faktor adalah data penilaian kinerja mahasiswa terhadap kualitas pelayanan laboratorium matematika yang sudah ditransformasi ke dalam bentuk interval dengan menggunakan metode MSI (Method Succesive Interval). Karena tujuan analisis faktor dalam penelitian ini adalah mengelompokkan atribut Kualitas pelayanan pelanggan ke dalam tingkat yang lebih tinggi.

Output analisis faktor di bawah ini hanya menyajikan hasil akhir dimana hanya melibatkan atribut-atribut yang layak dimasukkan dalam analisis.Setelah melampaui tahapan pengujian kelayakan seluruh variabel, lalu dilakukan ekastraksi faktor. Ekstraksi faktor adalah tahapan dalam analisis factor yang bertujuam menghasilkan sejumlah faktor dari data yang ada. Dalam penelitian ini metode yang digunakan adalah Principal Component Analysis.Dalam mengektraksi faktor digunakan eigenvalue yang menyatakan nilai variansi variabel manifes.Nilai ini menyatakan tingkat kepentingan relatif dari masing-masing variabel dalam menghitung varians 30 variabel manifes.

Dari hasil ektraksi tersebut menunjukkan bahwa dari 30 komponen faktor yang mungkin terbentuk, dengan batasan nilai eigen sebesar 1 didapatkan sebanyak 9 faktor. Artinya dari 30 atribut yang ada, akan diekstraksi menjadi 9 faktor.

Untuk menentukan variabel-variabel manifes masuk ke dalam faktor apa, metode rotasi yang digunakan dalam metode ini adalah metode varimax karena dengan metode ini hasil rotasi lebih mudah dibaca dibandingkan apabila menggunakan metode-metode lainnya seperti equimax, promax dan quartimax.

\section{Pembuatan Matrik QFD ( House of Quality) \\ Identifikasi Suara Pelanggan}

Atribut-atribut kualitas pelayanan yang telah dikelompokkan dengan menggunakan analisis faktor dijadikan masukkan utama dalam analisis QFD sebagai suara pelanggan dalam perencanaan kualitas pelayanan laboratorium matematika. Atribut-atribut yang menjadi suara pelanggan tersebut dapat dilihat pada Tabel 2.

\section{Pembentukan Matriks Perencanaan (Planning Matrix)}

Matriks perencanaan (Planning matrix) merupakan analisis terhadap voice of customer yang meliputi: tingkat kepentingan mahasiwa, performansi pelayanan, goal dan improvement difference, sales point, row weigth, normalized row weigth. 
Tabel 2 Suara Pelanggan (VOC)

\begin{tabular}{|c|c|}
\hline Atribut & Faktor \\
\hline Kelengkapan Hardware Komputer & \multirow{4}{*}{$\begin{array}{c}\text { Tangibles Fasilitas } \\
\text { Utama }\end{array}$} \\
\hline Kelengkapan Software & \\
\hline Kualitas Hardware Komputer & \\
\hline Ketersidian Buku di ELC & \\
\hline Respon Laboran & \multirow{6}{*}{ Kinerja Laboran } \\
\hline Keramahan Laboran & \\
\hline Kehadiran Laboran & \\
\hline Kesigapan Laboran & \\
\hline Ketepatan Jadwal & \\
\hline Kesopanan Laboran & \\
\hline Lama Waktu Pelayanan Lab & \multirow{4}{*}{ Kemampuan Dosen } \\
\hline Kejelasan Materi Dosen & \\
\hline Ketepatan Waktu Dosen & \\
\hline Tanggapan Dosen dari Pertanyaan & \\
\hline Kemampuan Laboran & \multirow{5}{*}{$\begin{array}{c}\text { Kenyamanan } \\
\text { Penggunaan }\end{array}$} \\
\hline Kenyamanan Ruangan & \\
\hline Penerangan Lampu Lab & \\
\hline Ventilasi Udara & \\
\hline Kualitas Meja dan Kursi & \\
\hline Kerapihan Ruangan & \multirow{4}{*}{$\begin{array}{l}\text { Kenyamanan } \\
\text { Laboratorium }\end{array}$} \\
\hline Kebersihan Lab & \\
\hline Design Interior & \\
\hline Ketepatan Penggunaan Lab & \\
\hline Suhu Ruangan Lab & \multirow{2}{*}{$\begin{array}{l}\text { Ketertiban dan } \\
\text { Suhu Ruangan }\end{array}$} \\
\hline Ketertiban Penggunaan Lab & \\
\hline Kapasitas Ruangan Lab & \multirow{2}{*}{ Empaty } \\
\hline Himbauan Penggunaan Lab dari Prodi & \\
\hline $\begin{array}{l}\text { Kelengkapan Sarana Pendukung } \\
\text { LCD, Webcam,dll }\end{array}$ & \multirow{2}{*}{$\begin{array}{l}\text { Fasilitas } \\
\text { Tambahan }\end{array}$} \\
\hline $\begin{array}{l}\text { Ketersediaan Fasilitas Internet, } \\
\text { Printing, dll }\end{array}$ & \\
\hline Jumlah Komputer & Jumlah Komputer \\
\hline
\end{tabular}




\section{Tingkat Kepentingan Mahasiswa (Importance to Customer)}

Jika dilihat dari tingkat kepentingan, secara umum mahasiswa menilai semua atribut pelayanan penting.Lima atribut utama yang dianggap penting oleh mahasiswa adalah kelengkapan software, kejelasan materi dari dosen, jumlah komputer, kualitas hardware komputer dan kemampuan laboran. Jika diperhatikan kelima atribut tersebut memang sangat berkaitan dan berpengaruh besar dalam kualitas pelayanan dan mutu praktikum itu sendiri. Sedangkan untuk 5 atribut yang dianggap tidak teralu penting oleh mahasiswa adalah designinterior, lama waktu pelayanan laboratorium, ketertiban penggunaan laboratorium, suhu ruang laboratorium dan ketepatan penggunaan laboratorium.

\section{Tingkat Kepuasan Mahasiswa dari Kinerja Lab Matematika (Customer SatisfactionPerformance)}

Jika dilihat dari tingkat kinerja, secara umum mahasiwa menilai cukup puas terhadap pelayanan yang diberikan dengan tingkat kinerja rata-rata bernilai 3. Lima atribut utama yang dianggap kinerjanya kurang baik oleh mahasiswa sehingga memberikan kepuasan yang kecil yaitu atribut ketersediaan fasilitas internet dan printing, jumlah komputer, kapasitas ruangan lab, design interior dan kelengkapan sarana pendukung webcam, LCD. Kelima atribut tersebut secara umum memang yang menjadi keluhan negatif mahasiswa dari hasil penelitian pendahuluan.Tentunya hal tersebut harus menjadi perhatian baik pihak laboratorium maupun pihak prodi untuk dapat meningkatkan kekurangan yang ada.

Sedangkan untuk lima atribut yang dianggap kinerjanya cukup baik oleh mahasiswa adalah suhu ruangan laboratorium, penerangan laboratorium, tanggapan dosen dari pertanyaan mahasiswa, kualitas meja dan kursi, kenyamanan ruangan dan kesopanan laboran. Item atribut tersebut memang ada pada kesan positif dari laboratorium matematika dari hasil penelitian pendahuluan.

\section{Menentukan Nilai Target (Goal)}

Goal merupakan level performance yang ingin dicapai oleh pihak laboratorium untuk memenuhi kebutuhan dan keinginan mahasiswa (cutomer need). Dapat diketahui bahwa ada beberapa atribut yang dibutuhkan oleh mahasiswa dan memiliki nilai target tinggi, lima terbesar diantaranya adalah kelengkapan software, kejelasan materi dari dosen, jumlah komputer, kualitas hardware komputer dan kemampuan laboran.

Dari hasil perbandingan antara tingkat kepuasan dengan goal yang ingin dicapai, diperoleh bahwa semua atribut penelitian belum ada tingkat kepuasan yang mencapai goal yang diharapkan.Sehingga semua atribut penelitian tersebut masih harus terus ditingkatkan untuk memenuhi harapan dan keinginan mahasiswa dalam menggunakan laboratorium matematika. 
Ada beberapa atribut yang dibutuhkan oleh mahasiswa dan memiliki nilai target tinggi, lima terbesar diantaranya adalah kelengkapan software, kejelasan materi dari dosen, jumlah komputer, kualitas hardware komputer dan kemampuan laboran.

Dari hasil perbandingan antara tingkat kepuasan dengan goal yang ingin dicapai, diperoleh bahwa semua atribut penelitian belum ada tingkat kepuasan yang mencapai goal yang diharapkan.Sehingga semua atribut penelitian tersebut masih harus terus ditingkatkan untuk memenuhi harapan dan keinginan mahasiswa dalam menggunakan laboratorium matematika.

\section{Menentukan Improvement Difference}

Improvement difference merupakan bobot kesulitan dalam upaya untuk meningkatkan dan perbaikan pelayanan oleh Laboratorium Matematika. Berikut adalah hasil perhitungan improvement difference dari Laboratorium Matematika dapat diketahui bahwa terdapat empat atribut dengan nilai improvement difference yang lebih besar dari 1.3, hal tersebut menunjukkan bahwa atribut tersebut merupakan atribut yang memiliki tingkat kesulitan tinggi untuk ditingkatkan. Keempat atribut tersebut adalah ketersediaan fasilitas internet dan printing, jumlah komputer, kapasitas ruangan laboratorium dan kelengkapan sotfware.

\section{Menentukan Sales Point}

Sales point merupakan informasi kemampuan memberikan pelayanan berdasarkan seberapa baik customer need terpenuhi. Nilainya adalah :

Nilai 1 : Tidak ada titik pelayanan

Nilai 1.2 : Titik pelayanan menengah

Nilai 1.5 : Titik pelayanan tinggi

Untuk menentukan nilai sales point ini, maka dilakukan wawancara secara langsung baik pada pihak Laboratorium Matematika dan pihak Prodi Matematika. Hasil wawancara mengenai Sales Point dapat dilihat pada Tabel 3.

\section{Menghitung Raw Weigh dan Normalized Raw Weight}

Perhitungan raw weight bertujuan untuk mengetahui tingkat kepentingan secara keseluruhan untuk menentukan prioritas perbaikan Laboratorium Matematika. Atribut yang memiliki nilai raw weight tinggi akan menjadi prioritas utama untuk ditingkatkan dalam memenuhi kepuasan mahasiswa.

Berdasarkan nilai raw weight, dapat disimpulkan lima atribut utama yang harus diprioritaskan dan diperhatikan oleh Pihak prodi dan laboratorium matematika dalam memberikan pelayanan optiomal kepada mahasiswa, yaitu: kualitas hardware komputer, jumlah komputer, kelengkapan sarana pendukung praktikum, kejelasan materi dari dosen dan kelengkapan hardware komputer. 
Tabel 3 Sales Point

\begin{tabular}{|c|c|c|c|}
\hline Faktor & Item & Atribut & $\begin{array}{l}\text { Sales } \\
\text { Point }\end{array}$ \\
\hline \multirow{4}{*}{$\begin{array}{c}\text { Tangibles } \\
\text { Fasilitas } \\
\text { Utama }\end{array}$} & $\mathrm{P} 12$ & Kelengkapan Hardware Komputer & 1.2 \\
\hline & $\mathrm{P} 13$ & Kelengkapan Software & 1.0 \\
\hline & $\mathrm{P} 14$ & Kualitas Hardware Komputer & 1.5 \\
\hline & $\mathrm{P} 16$ & Ketersidian Buku di ELC & 1.0 \\
\hline \multirow{6}{*}{$\begin{array}{l}\text { Kinerja } \\
\text { Laboran }\end{array}$} & $\mathrm{P} 1$ & Respon Laboran & 1.2 \\
\hline & $\mathrm{P} 2$ & Keramahan Laboran & 1.0 \\
\hline & P3 & Kehadiran Laboran & 1.0 \\
\hline & $\mathrm{P} 4$ & Kesigapan Laboran & 1.0 \\
\hline & P5 & Ketepatan Jadwal & 1.0 \\
\hline & $\mathrm{P} 6$ & Kesopanan Laboran & 1.0 \\
\hline \multirow{4}{*}{$\begin{array}{l}\text { Kemampuan } \\
\text { Dosen }\end{array}$} & $\mathrm{P} 8$ & Lama Waktu Pelayanan Lab & 1.0 \\
\hline & P9 & Kejelasan Materi Dosen & 1.2 \\
\hline & $\mathrm{P} 10$ & Ketepatan Waktu Dosen & 1.0 \\
\hline & $\mathrm{P} 11$ & Tanggapan Dosen dari Pertanyaan & 1.2 \\
\hline \multirow{5}{*}{$\begin{array}{l}\text { Kenyamanan } \\
\text { Penggunaan }\end{array}$} & $\mathrm{P} 7$ & Kemampuan Laboran & 1.2 \\
\hline & P18 & Kenyamanan Ruangan & 1.0 \\
\hline & $\mathrm{P} 21$ & Penerangan Lampu Lab & 1.2 \\
\hline & $\mathrm{P} 22$ & Ventilasi Udara & 1.2 \\
\hline & $\mathrm{P} 24$ & Kualitas Meja dan Kursi & 1.5 \\
\hline \multirow{4}{*}{$\begin{array}{l}\text { Kenyamanan } \\
\text { Laboratorium }\end{array}$} & $\mathrm{P} 17$ & Kerapihan Ruangan & 1.2 \\
\hline & P20 & Kebersihan Lab & 1.0 \\
\hline & $\mathrm{P} 23$ & Design Interior & 1.0 \\
\hline & $\mathrm{P} 28$ & Ketepatan Penggunaan Lab & 1.2 \\
\hline \multirow{2}{*}{$\begin{array}{l}\text { Ketertiban dan } \\
\text { Suhu Ruangan }\end{array}$} & P19 & Suhu Ruangan Lab & 1.5 \\
\hline & P30 & Ketertiban Penggunaan Lab & 1.0 \\
\hline \multirow{2}{*}{ Empaty } & $\mathrm{P} 25$ & Kapasitas Ruangan Lab & 1.0 \\
\hline & P29 & Himbauan Penggunaan Lab dari Prodi & 1.2 \\
\hline \multirow{2}{*}{$\begin{array}{l}\text { Fasilitas } \\
\text { Tambahan }\end{array}$} & P26 & $\begin{array}{l}\text { Kelengkapan Sarana Pendukung LCD, } \\
\text { Webcam,dll }\end{array}$ & 1.2 \\
\hline & $\mathrm{P} 27$ & $\begin{array}{l}\text { Ketersediaan Fasilitas Internet, } \\
\text { Printing, dll }\end{array}$ & 1.0 \\
\hline $\begin{array}{c}\text { Jumlah } \\
\text { Komputer }\end{array}$ & $\mathrm{P} 15$ & Jumlah Komputer & 1.2 \\
\hline
\end{tabular}




\section{Tanggapan Teknis Prodi Matematika(Technical Response)}

Diperoleh respon teknis Prodi Matematika terhadap kebutuhan mahasiswa sebagai berikut :

Tabel 4 Respon Teknis

\begin{tabular}{|c|l|c|}
\hline No. & \multicolumn{1}{|c|}{ Teknis Teknis } & Improvement \\
\hline 1 & Tingkat Empaty & $\uparrow$ \\
\hline 2 & Tingkat Assurance & $\uparrow$ \\
\hline 3 & Tingkat Reliability & $\uparrow$ \\
\hline 4 & Tingkat Responsiveness & $\uparrow$ \\
\hline 5 & Tingkat Tangibles & $\uparrow$ \\
\hline
\end{tabular}

Dari hasil diskusi, diperoleh lima respon teknis yang harus diperhatikan oleh pihak Prodi Matematika dalam memberikan pelayanan kepada mahasiswanya. Respon teknis ini masih dalam bentuk umum sehingga dalam aplikasinya, pihak Prodi Matematika dapat mengembangkan ide-ide kreatif guna memenuhi keinginan dari mahasiwa.

\section{Matriks Hubungan (Relationship Matrix)}

Matriks hubungan merupakan penilaian subjektif terhadap hubungan antara kebutuhan mahasiswa dan respon teknis Prodi Matematika.Penilaian tersebut dilakukan melalui pembicaraan dengan pihak Prodi Matematika mengenai sejauh mana respon teknis yang dikembangkan prodi dapat mempengaruhi pemenuhan kebutuhan mahasiswa.

Terlihat dari matriks hubungan padsa Tabel 5, tingkat tangibles dan assurance memengang peranan dominan dalam merespon kebutuhan mahasiswa. Tentunya ini sangat beralasan karena untuk dapat melakukan perbaikan dibutuhkan fasilitas praktikum yang lengkap serta jaminan penggunaan yang optimal sehingga proses praktikum dalam berjalan dengan baik sesuai dengan harapan dan keinginan mahasiswa.

\section{Menentukan Technical Matrix}

Technical matrix memberikan informasi mengenai prioritas perbaikan yang dapat dikembangkan oleh prodi matematika. Pada penelitian ini technical matrix hanya menjelaskan prioritas respon teknis yang dapat dikembangkan oleh prodi matematika tanpa proses benchmarking.

\section{Prioritas}

Prioritas dalam QFD menunjukkan urutan pelaksanaan technical response yang dapat dikembangkan.Prodi Matematika dapat memfokuskan perbaikan pelayanan berdasarkan technical response yang memiliki prioritas tertinggi. Urutan nilai prioritas technical response dapat dilihat pada Tabel 6. 
Tabel 5 Matrik Hubungan

\begin{tabular}{|c|c|c|c|c|c|c|}
\hline Item & Indikator & Empaty & Assurance & Reliability & $\begin{array}{l}\text { Responsive } \\
\text { ness }\end{array}$ & Tangibles \\
\hline $\mathrm{P} 12$ & $\begin{array}{l}\text { Kelengkapan Hardware } \\
\text { Komputer }\end{array}$ & & 3 & & & 9 \\
\hline $\mathrm{P} 13$ & Kelengkapan Software & & 3 & & & 9 \\
\hline $\mathrm{P} 14$ & $\begin{array}{l}\text { Kualitas Hardware } \\
\text { Komputer }\end{array}$ & & 3 & 3 & & 9 \\
\hline $\mathrm{P} 16$ & Ketersidian Buku di ELC & & 3 & & & 9 \\
\hline $\mathrm{P} 1$ & Respon Laboran & 3 & 1 & 3 & 9 & \\
\hline $\mathrm{P} 2$ & Keramahan Laboran & 1 & 9 & 9 & 1 & \\
\hline P3 & Kehadiran Laboran & 1 & 3 & 3 & 1 & 9 \\
\hline $\mathrm{P} 4$ & Kesigapan Laboran & 3 & 1 & 3 & 9 & \\
\hline P5 & Ketepatan Jadwal & 1 & 9 & 3 & 3 & \\
\hline $\mathrm{P} 6$ & Kesopanan Laboran & 1 & 9 & 9 & 1 & \\
\hline $\mathrm{P} 8$ & Lama Waktu Pelayanan Lab & & 9 & 3 & & 1 \\
\hline P9 & Kejelasan Materi Dosen & 1 & 3 & 9 & & \\
\hline $\mathrm{P} 10$ & Ketepatan Waktu Dosen & 1 & 9 & 3 & 1 & \\
\hline $\mathrm{P} 11$ & $\begin{array}{l}\text { Tanggapan Dosen dari } \\
\text { Pertanyaan }\end{array}$ & 3 & 3 & 3 & 9 & \\
\hline $\mathrm{P} 7$ & Kemampuan Laboran & & 3 & 9 & & \\
\hline $\mathrm{P} 18$ & Kenyamanan Ruangan & & 3 & & & 9 \\
\hline $\mathrm{P} 21$ & Penerangan Lampu Lab & & & & & 3 \\
\hline $\mathrm{P} 22$ & Ventilasi Udara & & & & & 3 \\
\hline $\mathrm{P} 24$ & Kualitas Meja dan Kursi & 1 & 3 & & & 9 \\
\hline $\mathrm{P} 17$ & Kerapihan Ruangan & & 3 & & & 3 \\
\hline $\mathrm{P} 20$ & Kebersihan Lab & & 3 & & & 9 \\
\hline $\mathrm{P} 23$ & Design Interior & & & & & 3 \\
\hline P28 & Ketepatan Penggunaan Lab & & 9 & 3 & 3 & \\
\hline $\mathrm{P} 19$ & Suhu Ruangan Lab & 1 & 3 & & & 9 \\
\hline P30 & Ketertiban Penggunaan Lab & 9 & 3 & & & 1 \\
\hline $\mathrm{P} 25$ & Kapasitas Ruangan Lab & & 3 & & & 9 \\
\hline $\mathrm{P} 29$ & $\begin{array}{l}\text { Himbauan Penggunaan Lab } \\
\text { dari Prodi }\end{array}$ & 9 & & 1 & & \\
\hline $\mathrm{P} 26$ & $\begin{array}{l}\text { Kelengkapan Sarana } \\
\text { Pendukung LCD, } \\
\text { Webcam,dll }\end{array}$ & & 3 & & & 9 \\
\hline $\mathrm{P} 27$ & $\begin{array}{l}\text { Ketersediaan Fasilitas } \\
\text { Internet, Printing, dll }\end{array}$ & & 3 & & & 9 \\
\hline $\mathrm{P} 15$ & Jumlah Komputer & & 3 & & & 9 \\
\hline
\end{tabular}


Tabel 6 Prioritas

\begin{tabular}{|l|c|c|c|}
\hline & $\begin{array}{c}\text { Arah } \\
\text { Perbaikan }\end{array}$ & $\begin{array}{c}\text { Tingkat } \\
\text { Kepentingan } \\
\text { SQC }\end{array}$ & $\begin{array}{c}\text { Percent Importance of } \\
\text { the SQC (\%) }\end{array}$ \\
\hline Tingkat Empaty & $\uparrow$ & 111.86 & 11.19 \\
\hline $\begin{array}{l}\text { Tingkat } \\
\text { Assurance }\end{array}$ & $\uparrow$ & 354.13 & 35.41 \\
\hline $\begin{array}{l}\text { Tingkat } \\
\text { Reliability }\end{array}$ & $\uparrow$ & 211.22 & 21.12 \\
\hline $\begin{array}{l}\text { Tingkat } \\
\text { Responsiveness }\end{array}$ & $\uparrow$ & 122.32 & 12.23 \\
\hline $\begin{array}{l}\text { Tingkat } \\
\text { Tangibles }\end{array}$ & $\uparrow$ & 448.30 & 44.83 \\
\hline
\end{tabular}

\section{Simpulan}

Secara umum terlihat prodi matematika berharap dapat memberikan pelayanan terbaik kepada setiap mahasiwanya. Dari hasil prioritas ini tanggapan teknis yang terpenting harus segera diimplementasikan oleh pihak prodi matematika adalah tingkat tangibles karena dari hasil prioritas diketahui bahwa nilai prioritasnya mencapai $44.83 \%$, yang berarti bahwa sebesar $44.83 \%$ kebutuhan mahasiwa akan terpenuhi dengan memenuhi atribut-atribut yang berkaitan dengan tangibles secara optimal. Prioritas kedua yang perlu diperhatika setelah tingkat tangibles adalah tingkat assurance.Nilai prioritas untuk tingkat assurance mencapai $35.41 \%$.Untuk tingkat assurance ini dapat dilakukan dengan mempersiapkan laboran yang berkompeten untuk mengelola laboratorium. Demikian halnya untuk tingkat reliability yang memiliki nilai prioritas sebesar $21.12 \%$, kemudian diikuti oleh tingkat responsiveness sebesar $12.23 \%$ dan yang terakhir menjadi prioritas adalah tingkat empaty dengan nilai priorotas sebesar $11.19 \%$.

\section{Daftar Pustaka}

1. Day, R.,G. 1993. Quality Function Deployment : Lingking a Company with its Customer, ASQC Quality Press, Milwaukee-Wisconsin.

2. Fandy, Tjiptono. 2001. Prinsip-Prinsip Total Quality Services, Edisi 2. Andy Offset:Yogyakarta

3. Jack B. Revelle, John W, Moran, Charles A. Cox. 1996 . THE QFD HANDBOOK. John Wiley \& Son, Inc : New York.

4. Montgomery, Douglas C. 1990. Pengantar Pengendalian Kualitas Statistik. Yogyakarta: Gadjah Mada University Press. 
5. Yamit, Zulian. 2001. Manajemen Kualitas Produk dan Jasa. Yogyakarta: Ekonisia. 